\title{
INDIVIDUAL IN CHRONOTOPE OF MODERN SOCIAL ORDER
}

\section{Romanenko S. S.}

\section{INTRODUCTION}

Throughout the course of history, emphasis in considering existence as a process and especially in the accelerated dynamics of social transformations of the present moment occurring at all levels of the human community is constantly shifting. In society, besides people there are no other active subjects, and if initially the psyche captures external, bodily differences of people and things, if in attempts to discover a certain order our consciousness connects objects with certain spatial dimensions, with the places of objects and subjects, the ontology and dynamics makes it necessary to take into account their distribution in time, their participation in its course and changes. This, in fact, makes people build multidimensional ontologies and develop chronotopic views for interpreting existence as a process.

In people's ordinary consciousness, the idea of a chronotope has somehow been manifested for quite a long time, at least since the middle of the $20^{\text {th }}$ century. At the same time, the chronotopic nature of social being is realized very vaguely, the problem of the relationship between space and time is bizarrely refracted in traditional stereotypes, its novelty is obscured, and its urgency is dulled, which causes not only everyday problems, but can also lead to harmful practical consequences.

The paradoxical presence of the problem of a chronotope in everyday behaviour and thinking is found at various levels of understanding sociality.

When ordinary consciousness operates with the ideas about social systems, for example, about individual countries, it primarily characterizes them through geographical, geometric, physical, and spatial concepts. The dimensions, position, access (or lack of access) to the ocean, the presence (absence) of minerals come to the fore. Hence the judgments about the strength, power, wealth, potential of the system derive. Time is present indirectly through history which is also comprehended in relation to a fixed space: it appears either as a tradition or as a dimension external to the characteristics of the system.

The very idea of modernity is paradoxical. Most people are aware that they live in a rapidly changing world. But only a few consider this evolution as changes in the connections of their own being, as changes in the nature of their own country, as the formation of new ways of human interaction. In this case, modernity is present primarily spatially, i.e., as the inevitability of 
coexistence in close contact of various social systems. They are modern in this view not because they develop and use a common metric of social processes, but because they exist simultaneously, being "inscribed" in the already filled (and in this sense, exhausted) space of the social world ${ }^{1}$.

One can speak not of a social chronotope, but of everyday topochrony, where time definitions are either immersed in spatial ones or distanced from them. The tradition of interpreting the forms of time through the forms of space is preserved in this approach. It would not be difficult to agree with this position if it were not for the changes in the life of the human community that in the second half of the 20th century affected almost everyone. The space of the human community is being transformed. But it is not changing physically. Nor geographically. Continents, regions, local civilizations have remained in the same places. However, we are talking more and more about the consolidation of contacts between them, about the problem of forming a common, single or global social space. The matter, in fact, should be not only and not so much about space as about time - about changes bringing together different social systems, about time that is changing qualitatively and under the guise of a common social space actually promoting a set of social systems simultaneously existing and interacting in an on-line mode.

So what or who caused these changes in time and space? Who is the bearer and subject of these changes? This issue is of urgent importance both for practical activity and for functioning worldview of people.

\section{The social field and the problem of the chronotope subjectness}

It seems that the situation with the problem of chronotope could be solved by the methodology of social science using an arsenal of modern scientific and theoretical tools and models of work with time and space, which were formed by social and humanitarian disciplines in the $20^{\text {th }}$ century. However, in this area the situation is quite controversial. Interest in chronotopic issues has grown significantly over the past fifty years. But there is no methodological certainty in the formulation of the problem of social chronotope. E. Giddens characterizes this situation quite sharply: "Without taking into account the recent work of geographers, we can safely say that social scientists failed to imagine and analyze the forms of organization of social systems in time and space"2.

An external stimulus for social science and social philosophy to develop the concept of a chronotope is the physical ideas of the early 20th century, connecting movement, space and time, outlining the tasks of studying space

\footnotetext{
${ }^{1}$ Ганчев П. Глобализация цивилизации и необходимость новой формы философии. Вопросы философии. 2007. № 8. С. 160-161.

${ }^{2}$ Гидденс Э. Устроение общества. М., 2003. С. 174.
} 
and time as forms of being of specific systems and their interaction. The concept of active, self-organizing, self-changing systems (L. von Bertalanfi, P. Anokhin, I. Prigozhin) supplemented by specific studies of space-time systems in geology, geography, biology, psychology are significant reinforcements of this stimulus. The turn of a number of sciences to the qualitative analysis of complex systems connects space and time with the organization of systems, with special relations between their elements, with the dimensionality of reproduction and change of these elements, and the interdependence of their functioning.

Society as a field of activity of various, but interdependent subjects is a space, but not a physical space where the subjects are placed, but the space formed by them, reproduced by their interdependent being.

The word "field" can be put in quotation marks, meaning that it is a metaphorical expression of a scheme that depicts human interactions as if they were happening on a plane. And here we have to note that this plane is a condition of manifestation that reveals a multisubjective dynamics, and at the same time there is a convention that hides its origin from the addition and multiplication of interacting subjects' forces. In other words, it turns out to be a "field", relative to the totality of operations of addition and multiplication of subject forces.

But since we are talking about the reproduction of social being, the dynamics of repetitions should be included in the scheme, and then the dynamics of changes. Therefore, in the scheme, the plane must somehow be completed with the volume, and the two-dimensional image becomes threedimensional. Subject actions in the aggregate "field" turn out to be interactions, and in the "volume" they are found as elements of different series, directions, "flows". Together with the voluminous schematism revealing the third dimension - the perspective of dynamics, the fourth dimension is revealed, which determines the change of each other's subjects, the change of each other's fields, that is, time is revealed. With this in mind, the "field" of activity can be defined as a vector field in which each subject position is associated with an action vector, a "line" of reproduction or change. On a flat section of volumetric schematism, the various flows in time directions of activity can be detected as directly combining ones. The effect of immediacy is created due to the fact that the "field" scheme is distracted from the temporal dynamics, and the dynamics of interaction or reproduction is manifested as simultaneity. But if a time parameter is introduced - and this is necessary when the combination of activity flows changes - we, in fact, are dealing with a variable vector field, a field that is constantly shifting, providing instant reflections of combinations of multisubject activity. 
The field hides its temporality, but it is charged with the activity, forces and interactions of various subjects. The meaning of the field as a methodological scheme is to precisely express the dynamics through statics, to combine cyclically conjugated moments of subject interactions and the process dynamics of the reproducing and changing of emerging structures by subjects. Hence it is possible to consider the field as a space of objective connections between positions and as a space generated by the interactions of various agents ${ }^{3}$.

The very understanding of the subject (s) unfolds in the interval between the representation that defines it in accordance with the position and its representation as a force, the reproducing and changing position. The subject is realized in the synthesis of assimilating the position and its transformation; it acts as a cyclic unity of kinematics and kinetics of activity. Therefore, it is possible to represent society as a plane on which social multisubjectness is inscribed in the logic of things, and to understand it as the combined tension of subject forces in which social forms are reproduced and generated.

The issue of subjects - carriers of social chronotope - gradually grew in philosophy and social science of the first half of the 20th century. The starting point was a philosophical criticism of absolute space-time; the next step was the refusal to consider the dynamics of society according to the spatiotemporal standards of nature, further attempts to understand the dynamics of individual social systems, the diversity of spatio-temporal continua in various sociocultural entities turned out to be natural. This very tendency to move away from classical ideas about absolute space / time required a special sociophilosophical and socio-humanitarian explanation. But the study did not reach this point remaining at the level of stating various social chronotopes and judgments about the severity of the characteristics of social and cultural systems in these differences. Time / space still has a subjectless, impersonal, supra-individual character, seems to be external to people and an alienated form, albeit a form belonging to society.

The habit of comprehending a chronotope subjectlessly is explained by the inertia of the classical methodology, which, contrary to fierce criticism of the social and humanitarian knowledge gaining independence, continued to operate in it at all levels. The need to "draw" a picture of society, starting with large forms: systems, structures, classes, groups, and then bring them under these systems or reduce the existence of human individuals to these forms for a long time in the future determines the methods of research in scientific

${ }^{3}$ Бурдье П. Социальное пространство и генезис классов. Социология политики. М., 1993. $336 \mathrm{c}$. 
social science and is transformed in it into a special kind of methodological stamp $^{4}$.

Contemporary social theorists and sociologists, of course, recognize that to comprehend social being, and therefore a social chronotope, without individuals is both uninteresting and unproductive. But the presence of individuals in social systems and structures is often interpreted in the spirit of the 19th century. For example, V. Ilyin, regarding the interconnectedness of individuals and the relationships that they create and maintain, insists on the possibility of their separate consideration. Moreover, as an argument, he uses the following metaphor: people resemble electrical conductors through which electric current passes; and just as one should not identify electric current with conductors, so, in fact, he believes, one should not identify people with their social structures, systems and spaces ${ }^{5}$. The question, in fact, is not about whether the structures of society can be considered separately from people or not. It is not difficult to imagine a number of situations when for research purposes we abstract ourselves from individuals and consider structures that exist as if by themselves. The question is about other thing: how accurate is the proposed metaphor for considering social chronotope or social space. The fact is that people are not only "conductors" of a social chronotope, but also the "current" that this chronotope creates and supports. They are not only elementary forms that conduct social energy, but also "nuclear" forces that create, reproduce and change this energy. Hence it is clear that without people's interaction no social chronotope is possible and there is no point in talking about social space and social time. It is not yet clear how the action of social systems and corresponding social theories is possible, where people seem to be absent or present in some forms that are not characteristic of their existence. This is part of an important socio-philosophical question: how and why is it possible to think about society evading the specific characteristics of human individuals?

Apparently, the special role of the problem of social chronotope is beginning to be realized due to the fact that in the second half of the $20^{\text {th }}$ century the forms of the spatio-temporal organization of social interactions at all levels - at the level of large social systems and at the level of large combined social entities, and at the level of direct interpersonal human contacts change significantly. Which of these changes in the preliminary plan can be distinguished?

${ }^{4}$ Кемеров В.Е. Меняющаяся роль социальной философии и антиредукционистские стратегии. Вопосы. философии. 2006. № 2. С. 61-78.

${ }_{5}$ Социальное пространство / Ильин В. Государство и социальная стратификация советского и постсоветского обществ (1917-1996). URL: http://socnet.narod.ru/library/ authors/llyin/syrata/html 
First of all, it is necessary to note the trends in the development of the people's qualitative activity, which lead them out of the dominance of large social structures; the social significance of individuals is less and less determined by their adaptability to structures and more and more by their personal contribution to practical results of their activity. Accordingly, the impact of individuals on the functioning, change and transformation of social structures becomes more noticeable. The spatio-temporal organization intrinsic to these structures ensuring their stability and preservation, is thus derived from the automatic mode and also finds its dependence on individuals, the nature and content of their interactions. It is a kind of separation of human interactions from fixed temporal and spatial standards. The external spatio-temporal "frame" of human activity loses its quasimaterial, quasi-naturalistic, objective and compulsory character and reveals signs of social connections being built by individuals themselves.

The significance of this moment becomes noticeable when we take into account the coordinated activity carried out at points of space extremely remote from each other.

Individual subjects do not appear in the focus of chronotopic problems because the large structures of society lose their significance. The thing is different: change, transformation, the formation of new forms of social chronotope is most clearly revealed at the level of jointly-divided activities of human individuals. It is at this level where the formation of the chronotope is revealed in the acts and contacts of social interactions; it is at this level where the significance of the formation phase for the reproduction of social forms is determined, which often seems to be an automatic, impersonal, quasi-natural process.

Social chronotope, like other structures, begins to lose its "appearance" in relation to the life of individuals. In its implementation and in its alternations it is dependent on them. Taking into consideration people's influence on the forms of sequence and the conjugation of their actions, on the choice of these forms, on the determination of their configuration, the chronotope, in a certain sense, is realized "inside" human interactions. "Inside" not in terms of the fact that it turns into a certain subjective, psychological reality, but in the sense that it, including this psychological reality, is reproduced and updated in actions distributed between subjects, in actions that depend on forces and abilities of subjects, on the connection of these forces and abilities, on their embodiment in certain objective results.

\section{Chronotope as a dynamic characteristic of social ties}

Social chronotope is a social form. But the form is of a special kind: it characterizes human societies and interactions as processes, moreover, as processes in which subjects can be directly connected and separated in time 
and space. In this aspect, social chronotope is a characteristic of indirect and direct social ties formed by a complex combination and interweaving of movable human interactions. Social chronotope is a social connection, but the connection is multidimensional, since it combines different lines of interdependence between people. Social chronotope is a form, but a dynamic form, existing and manifesting itself in the processes of social reproduction, arising in the process of renewing relations between people, creating new structures and institutions. The dynamism of social chronotope as a form is determined by its rootedness and distribution in the interactions of people and their self-realization. Out of relation to these activities, social chronotope cannot exist.

The interpretation of social chronotope as a dynamic connection between social subjects leaves an imprint on the understanding and presentation of other social forms.

What does this essentially mean? The adoption of the idea of social chronotope as fundamental in the methodological and worldview sense, prompts us to consider systems, structures, subjects, objects of social life as dynamic forms, as processes. In other words, we begin to represent the subjects (systems, structures, their relationships) not along with social processes, but as components of a procedural being, as various components and forms of this procedural being. The structure is not an external form where subjects and objects are placed, but a form of the procedural interdependence of these subjects in time and space. Social chronotope is revealed as a form linking different aspects of the processuality of social being.

The question of the processuality of social being is posed by discreteness itself, that is, by the discontinuity of human reality, the search for practical and theoretical "indicators" of forces or forms that "pull together" individual fragments of society into a whole. It is in the light of this issue that it becomes clear that fragments of social being do not exist on their own, but as segregations and individual moments of social processes. In these processes, they, in fact, reveal their nonphysical, i.e., social quality.

To understand the social process, the concept of activity is of particular importance. Under conditions when forms of direct dependence between people dominate, when their social connection is expressed in simple cooperation and compatibility, there is no special need for understanding the process of social being.

When the concept of social chronotope is introduced into the characterization of social being as fundamental from a methodological point of view, this essentially means that we begin to understand social being not only as a "general view" process in the spirit of classical concepts. This means that we are initially trying to present social being as an interconnection of 
processes, as a structure of processes, as their certain "polyphonic" combination.

In the framework of the chronotopic approach, activity is represented in its variability among different subjects, which allows people to work together to achieve effects that are not achievable with a simple addition of their forces. In other words, activity appears to be a multisubject process, providing the features of multisubjectness to the whole social ontology ${ }^{6}$.

Activity is subjective, discrete, individualized and at the same time ontological, continual, social as it connects various actions, functions, acts of self-realization of different individuals.

The chronotopic approach focuses on the dependence of social forms on people's activity.

These forms cease to be external objects, dictating to people the conditions of life and communication, but they themselves find their reproducibility, that is, the stability of being, in people's activity. In their activity, people confirm with their acts of creating and reproducing conditions their existential, ontological, object significance, that is, they are the main elements, components, "nuclear" forces of social being, and "nuclear" forms of social ontology.

Since subjects interact and are realized chronotopically, that is, through temporal and spatial connections, through the chronotope (chronotopes) they form different subject compositions that can be characterized as "combined subjects", groups, classes, etc. It is clear that chronotopes, and, therefore, subject compositions, can be made out in different ways. In this regard, large systems of society can be understood as different chronotopes, and a large society, in the form of a state, for example, can be interpreted as a chronotope of chronotopes.

Next arises the task of creating a typology of chronotopes. The solution to this problem will allow us to avoid the extremely abstract characteristics of social ontology, and, therefore, to maintain the orientation on its processivity and dynamics. In another aspect, the creation of such a typology will provide a more concrete idea of the subject content and design of a social ontology.

The distinguishing of the types of chronotopic relationships makes it possible to introduce a dynamic aspect in understanding the basic types of sociality. As the model of social chronotope is approaching special types of social ties, it inevitably comes into close contact with concrete scientific and concrete historical material. History itself then appears chronotopically as a connection of various chronotopes (types of society) in time and as an interaction of various chronotopes (societies, cultures, civilizations) in space ${ }^{7}$.

\footnotetext{
${ }^{6}$ Кемеров В.Е. Общество, социальность, полисубъектность. М., 2012. 252 с.

${ }^{7}$ Гумбрехт Г.-У. Современная история в настоящем меняющегося хронотопа. НЛО. 2007. № 83. C. 47.
} 


\section{Individual in the chronotope of small social groups}

Examining the chronotopic nature of social space, we turn to the study of the "society-individual" system as a whole and its part (element), where the whole is more, and not more than the sum of its parts, where the synergy of the individual and society is manifested in a single process of historical selforganization on the way to building society and the formation of man as a man in his biosocial integrity. What is the mechanism of this process?

In social space, the active subjects are individuals, their interaction lies at the basis of emerging associations, entities, groups and the emerging ties between them, social relations. Individuals themselves appear as carriers of these social relations existing at the same time in the form of individual and collective subjects of action ${ }^{8}$. The impact of society on individuals is carried out either directly or through groups. Exploring the combination in socialization of adaptation and isolation of a person in society, social psychologists distinguish such species as spontaneous socialization, relatively directed, relatively socially controlled socialization and self-change of a person (autopoiesis). At the same time, it is recognized that the most studied is positive socialization that meets the needs of society ${ }^{9}$. Specific groups serve as original translators of social experience; they are called the institutions of socialization (E. Belinskaya et al). Each group of people acts in relation to the external environment as a definite, in one way or another coordinated acting system, which has its own specific behavior, not reducible to the actions of the individuals who form it. The aggregate subject of human activity - the macrosubject - is also society itself.

It is worth mentioning that individuals, in addition to institutionalized influence, are influenced by each other. They interact with each other in everyday communication, solving a wide variety of everyday tasks, making social contacts at different levels. The process of socialization is carried out daily, throughout the whole life path of a person. Staying in public places, traveling in transport, staying in yards and in city streets, moving in a crowd or in a convoy, being in the theatrical public, in an audience, at a stadium or at mass events - all this is an ongoing process of interpersonal contacts, communication and interactions. Undoubtedly, at the same time, the exchange of information is largely spontaneous, the individual himself almost does not control this kind of situation. Herewith, the ever-increasing complication of forms of social life, the gigantic growth and development of mass means of

\footnotetext{
8 Маркарян Э. Вопросы системного рассмотрения культуры и человеческой деятельности. Исторический материализм как теория социального познания $и$ деятельности. М., 1972. С. 194.

${ }^{9}$ Мудрик А.В. Социализация человека. М., 2004. С. 33-40.
} 
consumption of culture and art works, mass forms of spending free time, the use of mass media make the process of individual's socialization constant and quite intense. In this regard, it can be noted that the vital activity of individuals, the acquisition of sociality by them is possible mainly through groups. Social groups are communities of interacting people, subsystems of the social organism, where the individual is included for a certain time or throughout his life ${ }^{10}$.

As G.M. Andreyeva emphasizes, social psychology proceeds from the social nature of its main object of study - the individual-society system, and reveals the significance of the group for the individual-member. Here, the group appears as a product of its own activity, as an activity system, as a collective subject, including its members in the system of social relations, determining their objective place in the social organism.

Joining a group takes shape for an individual in the consciousness of the group that accepted him through the idea of "we" about its members (including itself). A sufficient basis for group involvement in a communitygroup for an individual is a conviction of the fact of identity, social identity of his "I" among "we". This status for the individual from now on, divides all people into "we" and "they". Group norms and values, all the "baggage" of group consciousness, including the need, interests, opinions of the group, are received by the individual in co-ownership. For him, staying, participating in group life provides "the ground to follow, and not always simply in the form of accepting the external features of a person's appearance, but also in the form of reproducing patterns of behavior, or the whole lifestyle"11.

Borders are expanding and there are various multiplied forms of relationships and those forms of communication, direct and indirect contacts, on the basis of which events forming the people's future everyday life occur, spiritual formations, emotions, experiences are formed that leave a deep trace in thoughts, images stored in memory nourishing the imagination. So in the life of people the image of the world begins to function - habitual, generally familiar and sustainable. This image affects the spiritual life of the individual, his behavior, the scale of life values. The general image of the world in the representations of associations' members, certain individuals can be developed in their thoughts, imagination, and cause various experiences. Orientation to it as a personal or group space, behavior with the usual living conditions that recognized and developed a certain adaptability, leads to

${ }^{10}$ Романенко С.С. Индивид в хронотопе инициативного сообщества. Учёные записки Таврического национального университета им. В.И. Вернадского. Сімферополь, 2010. Т. 23 (62). № 2. С. 78-84. Серія: Філософія. Культурологія. Політологія. Соціологія.

${ }^{11}$ Андреева Г М. Социальная психология. М., 2004. С. 180. 
internalization, to a personal idea of one's own life world (the "lived-in world", as E. Husserl calls it, and L.S. Vygotsky called it a "zone of proximal development"). In the space of this "own" world, the results of the socialization process are formed, the skills of social contacts in various forms of society's life are developed. This serves to actualize the immediate, direct, diverse and multi-channel impact of social relations and public life on collective and individual subjects ${ }^{12}$.

The above-said shows that in sociologists' understanding, there is a spatial characteristic of social associations, but it appears to them out of touch with the dominant of time (the intentionality of the researchers themselves has shifted to a considerable extent to the activity of the subjects of the virtual world). So far, the term "chronotope" has not received scholars' proper recognition as an expression of the unity of temporal and spatial relations, which, according to M. Bakhtin, in its designation of the continuity of space and time, transforms the Kantian commandment about space and time as necessary forms of all knowledge ${ }^{13}$. As emphasized by L.A. Mikeshina ${ }^{14}$, Bakhtin not only borrowed the term chronotope from the concept of A.A. Ukhtomsky, but revealed it as "an expression of continuity in the objects of the natural and humanitarian and social sciences". It is M. Bakhtin, according to her, whom the merit of discovering and designating in the chronotope the basis for a modern understanding of the nature of temporality and spatiality belongs to, it has become the basis for fundamentally different from traditional ideas about the interdependence of man and the world ${ }^{15}$. The chronotope serves as a manifestation of temporal-spatial relationships; it is transferred from natural science to literature to mark the designation of the continuity of space and time; it is used as a category - a metaphor that clarifies the merging of spatial and temporal signs in a meaningful and concrete whole. The chronotope helps the individual, the "inner man", as M.A. Bakhtin puts it, to realize that "living means taking a value-oriented position in every moment of life". All this allows us to consider the chronotope as a "conceptually significant - a humanistic concept". Studying the nature of social processes, we shall turn to the theory of social relay races

\footnotetext{
12 Чистяков А.В. Социализация личности в виртуальном пространстве. Ростов н/Д., 2006. C. 41-45.

13 Бахтин М.М. Формы времени и хронотоп в романе. Очерки по исторической поэтике. Синергетическая парадигма. Когнитивно-коммуникативные стратегии современного научного знания. М., 2004. С. 509.

${ }_{14}$ Микешина Л.А. Философия Науки. Современная эпистемология. Научное знание в динамике культуры. Методология научного исследования: учеб. пособие. М., 2005. C. 405-409.

${ }^{15}$ Ibid. C. 410.
} 
proposed by M. A. Rozov ${ }^{16,17}$, in which he examines the relay nature of knowledge in science, reveals its cumatoid character and makes the general conclusion that "all social phenomena are kumatoids, which are based on the mechanism of social relay races"18. The term "kumatoid" in M.A. Rozov's understanding marks the undulating nature of a social object (from Greek Kuma is a wave). To clarify the unusual meaning of the characteristics of the phenomena of knowledge and social phenomena, the term "social relay" is proposed and its comparison with the wave is given.

The most characteristic features of social kumatoids are as follows: they transmit social experience, i.e. embody the mechanism of preserving tradition at all levels of the history development; they consist of samples' reproduction, i.e. are based on the implementation of a specific program - a social program, in whose composition samples are necessarily present, and the direct nature of these samples is important here; the existing social objects in the kumatoid are individuals and collective subjects, firstly, with time they change in composition, secondly, their components act when interacting with each other according to the standard (determined) program, and thirdly, this activity leads to the formation of structural changes of the kumatoid object itself - a society where social groups, associations arise, function, become active or break up.

It is important to note that every individual at any moment of his life turns out to be included in one or another role of this or that social community. Moreover, any individual at a time is a "performer" of a significant number of roles in many other kumatoids - social formations, herewith, interweaving, combining, overlapping of corresponding chronotopes takes place. In this way, a holistic co-occurrence of social phenomena and processes - social kumatoids - is realized.

The performance of social roles, in which the individual is included or even implanted throughout his life forms a colorful mosaic of the process of his socialization. He realizes himself and his abilities only when he is involved in interaction with other acting individuals. All individuals, to this or that degree are able to be active, but they transmit and "reproduce according to the model" the experience, the tradition of the social relay race already established at different levels of social chronotopes in which they are included.

\footnotetext{
${ }^{16}$ Розов М. А. Строение научного знания. Философия науки. Вып. 3. Проблемы анализа знания. М., 1997. С. 59-87.

17 Розов М.А. Теория социальных эстафет и проблемы эпистемологии. Смоленск, 2006. $499 \mathrm{c}$.

${ }^{18}$ Ibid. C. 70.
} 
Rozov M. A., of course, is also right arguing that the idea of a social relay race and its kumatoid nature "sets a special ontology in the understanding of social phenomena and focuses on identifying social programs of their interconnections and ways of existence" 19 . The inclusion of an individual in a certain group is expressed in the fact that their chronotopes are partially included in each other, can be intertwined, opposed, endure transformations under the influence of each other in certain situations.

Thus, it becomes quite obvious that the doctrine of the chronotope, as well as the theory of relay races - kumatoids - organically, like the theory of roles, fits into the characteristic of individual's being in the society-individual system, and this clarifies the inclusion of the individual in numerous social groups - subsystems of different levels forming the structure of an integrated society.

It is generally accepted to distinguish groups by volume as "small" and "large". Large groups are divided into spontaneous, unorganized and organized ones ${ }^{20}$.

In large groups, such specific regulators of human behavior as customs and traditions are developed, common facets of the lifestyle, language of the whole social group are formed. In the course of their life in culture, each large social group develops unique ideas about everyday reality, its own skills, their interpretation and understanding on the basis of which a certain picture of the world is created for this large group.

However, the most impressive, direct and procedurally effective impact on an individual takes place in small social groups. Social group, called the minor group in social psychology, constitutes the immediate life sphere, the primary layer of the individual's world that he recognizes as lived in, with the influence of which significant part of the impact of a holistic society is transferred, already in the form of situationally-conditioned acts of socialization. The nature, the character of these small communities, their diversity and variety reflect the pace of social development, the maturity and progressiveness of the processes of its components. A small group is understood as not big group, whose members are united by common social activity and are in direct personal communication which is the basis for the emergence of emotional relations, group norms and group processes ${ }^{21}$.

Active interest in small groups is determined primarily by the objective nature of small groups themselves, in which the involvement of an individual

\footnotetext{
${ }^{19}$ Розов М.А. Строение научного знания. Философия науки. Вып. 3. Проблемы анализа знания. М., 1997. С. 62.

${ }^{20}$ Андреева Г.М. Социальная психология. М., 2004. С. 149-151.

${ }^{21}$ Ibid. C. 187.
} 
from the very early age contacts with the outside world is obvious, traceable, and observable. The results of intra-group contacts-interactions, transformation of the behavioral plan are available for study and evaluation.

First of all, those specific signs of small groups are of interest, which determine the uniqueness and their special significance in the process of individuals' socialization due to the initial contact, the conjugation of chronotopes at least at a separate stage in the life of the included individual. The most important thing in a small group is the direct personal contacts of the group members. A small group is a real group of people who are present in a common chronotope and participating in joint activities. Their active participation forms the social relations that are historically present in the chronotope of a given society in terms of time, place of activity, type of this activity, which are carried out in the form of interpersonal relationships and direct contacts. The specifics of small groups are based on social preferences, values, attitudes chosen by the group, which in the field of specific social phenomena can be significantly transformed by the group itself and even differ from public ones. The group values are guided by the rules of behavior of group members, its very general activity, standards of moral preferences and approvals. Direct communication of participants in group activity encourages intra-group contacts (manifestation of affection or rejection, personal preference, recognition of personal authority and the allocation of referent subgroups by individual participants) $)^{22}$.

Small groups are of particular importance for an individual member, where a group living space, involvement in social activities and joint socio-cultural enrichment contribute to their formation as an individual and as a member of society. This significance for the individual is very accurately expressed in the reflections of Kalny I.I., who notes: "Only in small social formations does a modern person find what a "large" community does not give him. Only within the boundaries of "his bell tower" does he find understanding and sympathy, solidarity and hope for justice, for all these social characteristics are not abstract, but rather concrete, oriented towards the establishment of the moral principle of social life" 23 . He distinguishes small groups as the "secluded collective spaces" where it is difficult to distort information, and therefore it is

\footnotetext{
${ }^{22}$ Романенко С.С. Индивид в хронотопе инициативного сообщества. Учёные записки Таврического национального университета им. В. И. Вернадского. Сімферополь, 2010. Т. 23 (62). № 2. С. 78-84. Серія: Філософія. Культурологія. Політологія. Соціологія.

23 Кальной И.И. Идея гражданского общества: история и современный интеллектуальный диалог. Гражданское общество: идея, наследие соииализма и современная украинская реальность. Луганск, 2002. С. 88.
} 
difficult to manipulate public opinion. The openness of these entities determines people's direct participation in self-government, forcing them to voluntarily take upon themselves the measure of responsibility for themselves and others, ensuring the stability and strength of the unity of both social being and public consciousness.

The inclusion of an individual in a small group can be considered as the interaction of a part and the whole and as communication and interaction with their own kind. It is a single process as an activity of training and education, occurring at the same time. In this process, the individual simultaneously acts as a specific individual subject of his life and at the same time he is a component of the collective subject - a small group. Through a small group, the individual turns out to be an involved participant, the bearer of social relations of the whole society. Social relations, in fact, are represented by the society structuring, functioning and development of individuals grouped in mutual cooperation. An individual as an active participant in a small group - a social subsystem - is also included in the structure of society, i.e. thereby, "two in one" are realized in his life, which is inherent in part of any super complex whole ${ }^{24}$.

A diverse and varying mosaic of the micro-level of acts of human activity allows to form a macro-level of social processes, develop culture as a product and result of human life, and form the main product of the historical process the person himself.

In this kind of activity in the society of amateur, initiative associations in the most diverse spheres of public life, the motives and goals, interests and motivations of individuals, their intentions and inclinations, meaningful and spontaneous acts are fluctuating. At this microlevel of universal human activity, acts of human activity are added, connected and summarized.

The course of history, the evolutionary changes of a social organism are measured not by single acts of individuals, but by their combined conjugate unidirectional efforts as part of any groups, associations of people, starting with the family, work collective, initiative community, continuing with a social organization, political party, etc. where the macro-level of social processes is already being traced. These collective associations represent in the history course the subjects of one or another kind of activity, they show the degree of society's and each its member's freedom.

${ }^{24}$ Романенко С.С. Индивид в хронотопе инициативного сообщества. Учёные записки Таврического начионального университета им. В.И. Вернадского. Сімферополь, 2010. Т. 23 (62). № 2. С. 78-84. Серія: Філософія. Культурологія. Політологія. Соціологія. 


\section{CONCLUSIONS}

In the postindustrial world, which is replacing the industrial one, the strategy for considering and using chronotope is radically changing. This is due to at least two circumstances. Social space is deployed within the Earth, and its further distribution is not expected. If history has not ended, it will proceed in the forms of using time, filling it, intensifying it, synthesizing qualitative forms of human activity and interactions.

In the emerging social space there simultaneously exist societies / states, cultures / civilizations, that is, spaces belonging to different social and, therefore, chronotopic types. In a practical sense, there are problems of conflict and coordination of different types of chronotopes. The theoretical and methodological plan determines the task of interpreting social chronotope as a multidimensional system combining various regional chronotopes with their special value and regulatory "mechanisms" and a global chronotope that makes possible political, legal, transport, cultural, informational communications on the scale of the human community.

Small groups are of particular importance for an individual, where group living space, involvement in social activity and joint socio-cultural enrichment contribute to their formation as an individual and as a member of society.

By means of a small social group, an individual turns out to be an involved participant, a bearer of social relations of the whole society. Social relations, in fact, are represented by society's structuring, functioning and development of individuals grouped in mutual COoperation. Involvement in such kind of social structures allows an individual to exercise his free choice of lifestyle, the possibility of self-improvement, self-realization, self-affirmation. The phenomenon of such social communities, which are the only ones today representing the prototype of the cell where an individual is able to independently determine his activity as a subject constructively creating his life path, his own lifestyle, and also realizing himself as a person, can be studied by developing interdisciplinary research and comprehensive understanding by modern science.

\section{SUMMARY}

The article is devoted to the concept of social chronotope and its role in the development of modern social and humanitarian knowledge. The action of this concept in the forms of modern social methodology and designing of a new social ontology is shown. The main features of social chronotope as a concept of the interdependence of social space and social time, human activity and social dynamics are characterized. The author concludes that the concept of social chronotope stimulates serious changes in the methodology of modern social and humanitarian knowledge. In the study of the chronotopicity of 
social space, the system "society - individual" was considered on the example of small groups, where the synergy of an individual and society in a single process of historical self-organization is manifested.

\section{REFERENCES}

1. Андреева Г.М. Социальная психология. М., 2004. 365 с.

2. Бахтин М.М. Формы времени и хронотоп в романе. Очерки по исторической поэтике. Синергетическая парадигма. Когнитивнокоммуникативные стратегии современного научного знания. М., 2004. C. 507-514.

3. Бурдье П. Социальное пространство и генезис классов. Социология политики. М., 1993. 336 с.

4. Ганчев П. Глобализация цивилизации и необходимость новой формы философии. Вопросы философии. 2007. № 8. С. 160-161.

5. Гидденс Э. Устроение общества. М., 2003. 528 с.

6. Гумбрехт Г.-У. Современная история в настоящем меняющегося хронотопа. НЛО. 2007. № 83. С. 47.

7. Кальной И.И. Идея гражданского общества: история и современный интеллектуальный диалог. Гражданское общество: идея, наследие соииализма и современная украинская реальность. Луганск, 2002. С. 77-91.

8. Кемеров В.Е. Меняющаяся роль социальной философии и антиредукционистские стратегии. Bonocbl. философии. 2006. № 2. C. $61-78$

9. Кемеров В.Е. Общество, социальность, полисубъектность. М., 2012. $252 \mathrm{c}$.

10. Маркарян Э. Вопросы системного рассмотрения культуры и человеческой деятельности. Исторический материализм как теория соииального познания и деятельности. М., $1972.320 \mathrm{c.}$

11. Микешина Л.А. Философия Науки. Современная эпистемология. Научное знание в динамике культуры. Методология научного исследования: учеб. пособие. М., 2005. 464 с.

12. Мудрик А.В. Социализация человека. М., 2004. 170 с.

13. Розов М.А. Строение научного знания. Философия науки. Вып. 3. Проблемы анализа знания. М., 1997. С. 59-87.

14. Розов М.А. Теория социальных эстафет и проблемы эпистемологии. Смоленск, 2006. 499 с.

15. Романенко С.С. Индивид в хронотопе инициативного сообщества. Учёные записки Таврического национального университета им. В.И. Вернадского. Сімферополь, 2010. Т. 23 (62). № 2. С. 78-84. Серія: Філософія. Культурологія. Політологія. Соціологія. 
16. Социальное пространство / Ильин В. Государство и социальная стратификация советского и постсоветского обществ (1917-1996). URL: http://socnet.narod.ru/library/authors/Ilyin/syrata/html

17. Чистяков А.В. Социализация личности в виртуальном пространстве. Ростов н/Д., 2006. 184 с.

Information about the author:

Romanenko S. S.,

Candidate of Philosophical Sciences, Associate Professor at the Department of Sport Games, State institution "South-Ukrainian National Pedagogical University named after K. D. Ushynsky" 26, Staroportofrankivska str., Odesa, 65020, Ukraine 